\title{
ENCYKLIKA GRANDE MUNUS A JEJ ODOZVA U SLOVENSKÝCH KATOLÍKOV ${ }^{1}$
}

\author{
The Encyclical Grande Munus and a Response \\ to It From the Slovak Catholics
}

\author{
Peter Ivanič
}

DOI: 10.17846/CL.2019.12.2.98-106

\begin{abstract}
IVANIČ, Peter. The Encyclical Grande Munus and a Response to It From the Slovak Catholics. Pope Leo XIII issued the Encyclical Grande Munus on the 30th of September 1880, right at the beginning of his long pontificate. He noted apostolical merits of Sts. Cyril and Methodius there and extended their feast to the whole Church. The feast of Sts. Cyril and Methodius was set on the 5th of July by the Pontiff. The great thanksgiving pilgrimage of the 1.400 Slavs to Rome between the 25th of June and the 5th of July 1881 was a direct answer of the Slavs to the emphasis, which the Pope placed on the importance of the CyrilloMethodian heritage by the Encyclical Grande Munus, and his favour to the Slavonic cause. The representatives of the Slovak Catholics favourably reacted to the Encyclical and atteded the pilgrimage. The author of the paper will deal with the reaction of the Slovak Catholics to the two aforementioned events in the press in the 19th century.
\end{abstract}

Keywords: Leo XIII, Sts. Cyril and Methodius, Grande munus, pilgrimage, Slovaks, Byzantium

Abstrakt: IVANIČ, Peter. Encyklika Grande munus a jej odozva u slovenských katolíkov. Pápež Lev XIII. vydal hned’ na začiatku svojho dlhého pontifikátu, 30. septembra 1880, encykliku Grande munus, v ktorej pripomenul apoštolské zásluhy sv. Cyrila a Metoda a rozšíril sviatok svätého Cyrila a Metoda na celú Cirkev. Slávenie sviatku ustanovil na 5. júla. Jasnou odpovedou Slovanov na pápežovu priazeň voči slovanskej otázke a na vyzdvihnutie významu cyrilo-metodského dedičstva prostredníctvom encykliky Grande munus bola vel'ká dakovná pút 1400 Slovanov do Ríma, ktorá sa konala v dňoch 25. júna - 5. júla 1881. Predstavitelia slovenských katolíkov priaznivo reagovali na encykliku a zúčastnili sa púte. V príspevku sa zameriame na odozvu slovenských katolíkov na tieto dve udalosti v dobovej tlači.

Klúčové slová: Lev XIII., sv. Cyril a Metod, Grande munus, pút', Slováci, Byzancia

V roku 1878 sa pápežom stal Lev XIII. (1878 - 1903). Bolo to v čase, ked’ sa Svätá stolica ocitla v Európe izolovaná. Počas svojho pontifikátu medzinárodne posilnil prestíž a morálne postavenie pápežstva. Lev XIII. bol uznávaný ako autorita nielen morálna, ale aj diplomatická. Významne zasahoval do svetového diania. Jeho diplomacia bola založená na univerzálnosti katolíckej cirkvi. Snažil sa nadviazat' diplomatické vzţahy s Ruskom, ktoré boli prerušené za Pia IX. (1846 - 1878), a zblížit sa s pravoslávnym svetom (Tolomeo 2005, 195-210; Trincia 2005, 115-136).

Táto práca bola podporovaná Agentúrou na podporu výskumu a vývoja na základeZmluvy č. APVV-16-0116. 


\section{Encyklika Grande munus}

Pápež Lev XIII. (1878 - 1903) vydal hned’ na začiatku svojho dlhého pontifikátu, dňa 30. septembra 1880 encykliku Grande munus ${ }^{2}$, v ktorej pripomenul apoštolské zásluhy sv. Cyrila a Metoda a rozšíril sviatok svätého Cyrila a Metoda na celú Cirkev. Slávenie sviatku ustanovil na 5. júla. Vydaním encykliky Grande munus sa stali solúnski bratia, apoštoli Slovanov, spoločným bohatstvom krestanského Západu. Zaradenie sviatku na 5. júla s odkazom na predchádzajúce rozhodnutia Pia IX. poukazuje na vplyv spoločnej iniciatívy biskupov v Habsburskej monarchii, ktoré bolo pre takéto určenie sviatku rozhodujúce (Ambros 2018, 57). Príležitostou pre publikovanie tejto encykliky bolo tisíce výročie vydania apoštolského listu Industriae tuae pápeža Jána VIII. z roku 880 a deň vydania encykliky Grande munus bol dňom liturgickej spomienky na svätého Hieronyma, ktorého považovali Chorváti za svojho národného patróna. Práve v účinkovaní sv. Cyrila a Metoda videl Lev XIII. vzhladom na svoj ekumenický a európsky program nasledovaniahodný príklad aj pre budúcnost'. V katolíckom svete sa dovtedy svätí Cyril a Metod, s výnimkou Moravy, Slovenska a Chorvátska, spomínali iba ako mučeníci. Ruskí jezuiti, ktorí pôsobili v spoločnosti L'œuvre des saints Cyrille et Méthode v Paríži, najmä kňaz a historik Paul Pierling (1840 - 1922) narodený v Petrohrade, patrili medzi hlavných inšpirátorov encykliky, ale neboli jediní. Aj v Rímskej kúrii bolo niekolko významných osobností, ktoré si priali zjednotenie cirkvi. Za najväčšieho inšpirátora encykliky je považovaný kardinál Mariano Rampolla del Tindaro (1843 - 1913), ktorý bol aktívny vo Svätej kongregácii pre šírenie viery (Congregazione di Propaganda Fide), kde mal na starosti východné oblasti. Poznal vel’mi dobre zložitú situáciu katolíkov vo východnej Európe zo správ od kňazov, biskupov, ale aj apoštolských delegátov. On pochopil návrhy, ktoré dostal od Paula Pierlinga, aby dal nový impulz kultu svätých apoštolov Solúnskych (Tolomeo 2015, 215). V roku 1879 totiž predložil Paul Pierling správu o Balkáne kardinálovi Giovannimu Simeonimu. V nej upozornil na významnú úctu k sv. Cyrilovi a Metodovi, ktorú k nim mali všetky slovanské národy (Tolomeo 2015, 210-211). V súvislosti s vydaním encykliky sa uvádzajú ešte štyri výrazné osobnosti vtedajšieho katolíckeho sveta: štátny sekretár Leva XIII. Ludovico Jacobini (1832 - 1887), apoštolský nuncius vo Viedni Serafino Vannutelli (1834 - 1915), jeho brat dominikán Vincenzo Vannutelli (1836 - 1930) a chorvátsky biskup Josip Juraj Strossmayer (1815 - 1905). Ludovico Jacobini bol titulárnym biskupom v Solúne, rodnom meste svätého Cyrila a Metoda. Pred menovaním do funkcie štátneho sekretára vykonával úlohu apoštolského nuncia vo Viedni od 24. marca 1874 do 18. novembra 1880. Jeho nástupcom sa stal Serafino Vannutelli, ktorý vykonával úrad apoštolského nuncia vo Viedni do 27. apríla 1887. Bol v úzkom kontakte s chorvátskymi a slovenskými vzdelancami, zvlášt s djakovským biskupom Josipom Jurajom Strossmayerom, Františkom Sasinkom, Jánom Palárikom, Ferkom Urbánkom a Andrejom Kmetom. Apoštolský nuncius Vannutelli vážne obviňoval viedenský dvor a zvlášt budapeštiansku vládu z prílišného nacionalizmu, ktorý bráni slovanským národom Habsburskej monarchie uplatnit si prirodzené právo na slobodu a podporu národných hodnôt (Hromják 2013: 549-550). Jeho brat Vincenzo Vannutelli pôsobil v rokoch 1871 až 1873 v Konštantínopole, kde sa bližšie zoznámil s ortodoxným krestanstvom. V neskoršom období bol úzkym spolupracovníkom pápeža Leva XIII., ktorému radil práve v otázkach východnej politiky (Tolomeo 2015, 215) .

Encyklikou Grande munus pápež plne sledoval svoj ciel' realizovat myšlienku katolíckeho slavizmu. Vyzdvihnutím misionárskej činnosti sv. Cyrila a Metoda medzi Slovanmi poukázal na spoločné dedičstvo východných a západných Slovanov, pričom nezabudol pripomenút ich spojenie so Svätou stolicou. Slovenský cirkevný historik Luboslav Hromják zdôrazňuje, že pod pojmom katolícky slavizmus treba rozumiet politicko-náboženské úsilie pápeža Leva XIII. o zjednotenie

\footnotetext{
Text encykliky je v plnom znení prístupný na internete (Grande munus 2019).
} 
všetkých Slovanov v lone katolíckej Cirkvi pod vedením rímskeho pápeža prostredníctvom úcty k svätému Cyrilovi a Metodovi. Prostredníctvom tejto encykliky došlo k posilneniu autority pápeža u Slovanov (Hromják 2010).

\section{Slováci a encyklika Grande Munus}

Encyklika Grande munus našla odozvu aj v slovenskej dobovej tlači. Slováci a predovšetkým slovenskí predstavitelia katolíkov velmi pozitívne reagovali na samotnú encykliku, pretože po Rakúsko-uhorskom vyrovnaní v roku 1867 bolo pripomínanie cyrilo-metodského kultu vzhladom na politicko-spoločenskú situáciu zatlačené do úzadia. Dušan Škvarna a Adam Hudek $(2013,50)$ výstižne charakterizujú situáciu v tomto období slovami: „Propagácia a pestovanie kultu Cyrila a Metoda ako symbolu slovenskej i slovanskej identity a opory emancipácie Slovákov korelovali s národnostnou politikou voči Slovákom a so stavom slovenskej spoločnosti, jej kultúry a politiky. Mad’arské elity, ktoré chápali kult Cyrila a Metoda ako konkurenta uhorských symbolov, sa usilovali, aby bol tento kult vytlačený z viditelných miest a pokial'možno pretrvával v marginálnej pozícii posilňujúcej proces zabúdania“. O tom, že úcta k sv. Cyrilovi a Metodovi bola po roku 1867 potlačovaná, svedčí príklad vzniku Spolku sv. Vojtecha. Hlavným iniciátorom vzniku spolku bol Andrej Radlinský, ktorý ho chcel pomenovat práve menami slovanských apoštolov. Ostrihomský arcibiskupský úrad síce vznik spolku nakoniec povolil, ale pod podmienkou, že neponesie názov sv. Cyrila a Metoda. Radlinský predsa len spomenul solúnskych bratov v prvom paragrafe programu spolku, kde sa o názve spolku uvádza: „spolok dostáva meno svoje od sv. Vojtecha, patróna královstva uhorského a bude sa teda nazývat" ,Spolkom sv. Vojtecha“, bude stát pod ochranou nepoškvrnenej Rodičky Božej Panny Márie, sv. Cyrilla a Methoda, ktorí Slovanov na vieru Kristovu obrátili, a sv. Vojtecha." (Hanakovič 2005, 25-39).

Cyrilo-metodská téma sa na krátky čas opät dostala do povedomia nielen slovenských katolíkov, ale aj verejnosti v roku 1880, a to práve vd’aka encyklike Grande munus. Slovenský preklad textu bol zverejnený v novembrovom čísle Katolíckych novín (KN 1880, 161-164). Encyklika Leva XIII. následne našla odozvu vo viacerých príspevkoch Katolíckych novín v roku 1881 . V marcovom čísle uverejnil v článku Nuž a my Slováci, čo? katolícky kňaz a historik František Vítazoslav Sasinek (1830 - 1914) (1881b, 36-37) zaujímavú rozpravu o encyklike. V úvode píše, že pápež sa ňou prihovoril ku všetkým Slovanom, ktorí vysielajú k nemu svojich reprezentantov, aby sa za ňu podakovali. Konštatuje, že jedine Slováci mlčia, ale nie vlastnou vinou. V texte konkrétne uvádza: „Mlčíme natolko, že nám zamykajú ustá, aby sme verejne neprihlásili sa $k$ nebeským miláčkom našim, ss. Cyrillovi a Methodovi... Mlčíme od žialu, že prenasledovanie mien ss. Cyrilla a Methoda nezničilo ani tisícletie. Či nie? Daj tie mená pri krste, spomeň jich na kazatelnici, a zakúsiš. Ozdob tvoj príbytok obrazom týchto nesmrtelných Dobrodincov Slovanstva, a zakúsiš. Pestuj dla príkladu ss. Cyrilla a Methoda krestanskú slovenskú literatúru, a zakúsiš. Na konci príspevku konštatuje: „Dá Boh aj slobodu šlapaným Slovákom, a títo potom oddychnuvše si z hlbin srdca, shromaždia sa okolo Kristu verných pastierov, ktorí znajú miloval ovce Ježiša Krista, a zanesú radostný hlas do spitého mesta. Bude on svedkom rozpinaného katolického Slováka nad uznaním nesmrtelných zásluh ss. Cyrilla a Methoda".

V nasledujúcom aprílovom čísle Katolíckych novín uverejnil advokát Franko Kabina (1881, 54-55) návrh, aby sa zorganizoval výbor zložený z kňazov a svetských osobností, ktorý by zostavil pozdravnú tzv. adresu (pozdravný a d’akovný list pápežovi) a zároveň vyzval všetkých slovanských krestanov k jej podpisu. Tento výbor sa mal ustanovit už dňa 23. mája 1881 v Nitre, kde bol biskupom Augustín Roškováni (Roskoványi) (1859 - 1892), ktorého označil ako nástupcu sv. Metoda. Podpísaná adresa spolu s pekným darom sa mala osobitnými vyslancami dňa 5. júla odovzdat' 
priamo pápežovi. Kabina vyzýva čitatelov priamo slovami: „Adressu musíme zaniest’ sv. Otcovi, adressu dôvery a uveličit srdce Jeho, aby aj On pevnou nádejou hladel na nás, tak ako my nádejou ním skriesenou hladíme Naňho a na seba. My sme krestania katolíci a nikto neotroví srdcia naše, aby sme nedali výraz šlachetným citom svojim, nik nepoviaže vôlu našu, aby sme ned’akovali sv. Otcovi za naše uvelebenie, nik neokuje ruky naše, aby sme nepodpisovali adressu určenú oslávil naše smýšlanie oproti sv. Stolici... A nám Slovákom po samom predku sluší, aby sme počiatok urobili, lebo ved' pod našimi Tatrámi počali sv. Cyrill a Method hlásat slovo Božie. My verní súc jich učeniu a príkladu, nesmieme si dat vyrvat prvenstvo...". Táto výzva zostala bez odozvy, pretože v máji prišlo z Prahy pozvanie na uskutočnenie cyrilo-metodskej púte s pod’akovaním pontifikovi Levovi XIII. do Ríma, ktorá sa mala konat 5. júla. List, ktorý zostavili 5. mája 1881 v Prahe prepošt kapituly na Vyšehrade Václav Štulc a doktor bohoslovia a spoluriaditel’ arcibiskupského seminára v Prahe František zo Schönbornu, bol v plnom znení uverejnený v júnovom čísle Katolíckych novín (KN 1881a, 81-82). Na túto výzvu hned’v tom istom čísle reagoval František Vítazoslav Sasinek (1881e, 82) v príspevku Vyzvanie. V ňom deklaroval svoje odhodlanie zúčastnit’ sa púte do Ríma, kde by chcel odovzdat pozdravnú adresu priamo Levovi XIII. Navrhol tu aj konkrétny text pozdravnej adresy, ktorý znel: „Najsvätejší Otče! My niže písaní katolícki Slováci, verní dedičia toho svätého Ježiša Krista evangeliuma, ktoré nesmrtelnej pamiatky slovanskí Apoštolovia, svätí Cyrill a Method na brehoch Moravy, Váhu a Hronu (riek to hornieho Uhorska) hlásali otcom našim, s najhlbšou pokorou približujeme sa $k$ apoštolskému trónu Vašej Svätosti, z rozplesaného srdca vzdávajúce ty najvrúcnejšie diéky, že Vaša Svätost velké zásluhy svätých Cyrilla a Methoda celej svätej Cirkvi oznámit' slávu a tak slávu jejich pre veškerým svetom uveličit ráčila; neprestávajúce spolu vrelými modlitbami prosit Boha všemohúceho, aby Vašej Svätosti ráčil udelit dožitie toho túženého okamženia, v ktorom by všetky slovanské kmeny s jednou vierou shromáždiii sa okolo nepodvratného prestolu sv. Petra apoštola, jako jich niekdy ss. Cyrrill a Method za doby Mikuláša I., Adriana Il. a Jána VIII., rímskych Pápežov, okolo neho boli shromáždili.“

Vdaka tejto výzve a osobnej iniciatíve Sasinka sa podarilo vo velmi krátkom čase pod zdravicu vyzbierat 3930 mužských podpisov. Jednotlivé hárky zviazali a graficky pripravili v Kníhtlačiarskom účastinárskom spolku v Turčianskom Sv. Martine (Parenička 2015, 143). Sasinek, okrem podpisov pod adresu, zbieral aj milodary pre Leva XIII. Na stránkach Katolíckych novín uviedol, že 4. júla odovzdal v Ríme ostrihomskému kanonikovi Jánovi Krstitelovi Jurigovi 1438 lír v zlate a 20 centisimov (Sasinek 1881a, 126). Po návrate z Ríma František V. Sasinek (1881c, 125-126; 1881d, 104$105 ; 1881 f$, 2-3) podrobne informoval o svojej púti a samotnej audiencii u Sv. Otca na stránkach Katolíckych aj Národných novín.

\section{Ďakovná pút' Slovanov do Ríma v roku 1881 a jej odozva}

Ďakovná pút Slovanov do Ríma sa konala v dňoch 25. júna - 5. júla 1881. Slováci sa na púti nemohli zúčastnit’ v samostatnej delegácii pre priamy odpor uhorskej vlády. Aj napriek tomu sa zúčastnili d’akovnej púte v spoločnej 250-člennej delegácii s Čechmi a Moravanmi. Lubomír Hromják $(2013,559)$ poukazuje na skutočnost', že počet Slovákov na d’akovnej púti Slovanov nie je úplne známy, pretože v správach nuncia Serafina Vannutelliho je len uvedené, že počet českej a moravskej delegácie sa zvýšil z 200 na 250 kvôli pripojeniu sa Slovanov z Uhorska do tejto delegácie. Pod týmto termínom označoval nuncius Vannutelli vo svojich správach pre Rímsku kúriu zväčša Slovákov. Na základe tejto informácie sa Hromják $(2013,559)$ domnieva, že na tejto púti sa mohlo zúčastnit až 50 Slovákov ako súčast 250-člennej českej a moravskej delegácie. Predpokladá, že viacerí slovenskí pútnici $\mathrm{v}$ tomto zozname nefigurovali $\mathrm{z}$ obáv $\mathrm{z}$ možných reštriktívnych krokov uhorských úradov a vlády. Upozorňuje na prípad účastníka púte Františka V. Sasinka, 
na ktorého uhorské úrady vydali v roku 1882 zatykač za buričskú činnost’ proti Uhorsku, a preto následne odišiel do Prahy. Na druhej strane uvádza, že v celkovom zozname 1400 slovanských pútnikov, ktorý uviedli noviny L’Osservatore Romano 7. júla 1881, figurovalo len 8 slovenských pútnikov, z toho sedem kňazov a rolník z Holíča Ján Malík (Hromják 2013, 559). Z kňazov to boli okrem Sasinka ostrihomský kanonik Ján Krstitel' Juriga (1806 - 1888), spoluzakladatel' Matice slovenskej a Spolku sv. Vojtecha Juraj Slota (1819 - 1882), dekan Pružinského dištriktu Štefan Závodník (1813 - 1885), račiansky farár Móric Alster (1861 - 1894), farár na odpočinku a bývalý predseda Spolku sv. Vojtecha Ján Blaho (1815 - 1893) a napokon katechéta na dievčenskej škole v Ostrihome a neskorší správca Spolku sv. Vojtecha Andrej Kubina (1844 - 1900). Tento nízky počet možno považovat za reálny aj z toho dôvodu, že sa vyskytuje v správach priamych účastníkov púte. ${ }^{3}$ Tieto mená uvádza vo svojom spise Pout Slovanu do Ríma ke dni sv. naších apoštolu Cyrilla a Methodeje r. 1881, ktorý bol prídavkom k publikácii Bohumila Hakla Cesta do Ríma a dále do Neapole a Pompeji, moravský katolícky kňaz a vlastenec František Koželuha. V jeho zozname nájdeme aj Františka Přecechtěla, ktorý mal pôsobit ako františkán na Slovensku (Koželuha 2004, 97-99). Priezvisko však svedčí o jeho českom pôvode. Ako sa podarilo zistił Jozefovi V. Gajdošovi (1970, 74), tak členom františkánov v Bratislave bol aj P. Maternus, ktorého prezývali Precechtiel. Gajdoš však vyjadril pochybnost', že by do Ríma išiel s ostatnými Slovákmi. Tohto františkána nespomína vo svojich spomienkach ani priamy účastník púte Móric Alster, ktorý okrem mien doslova uvádza: „Zo Slovenska sa 7 kňazov a 1 sedliak $z$ Holíča odhodlalo na pút, ktorú Madari tiež nenávideli..." (Gajdoš 1970, 70). Uhorské úrady totiž robili obštrukcie s vystavením cestovných dokladov. Svedčí o tom príklad Františka Sasinka, ktorý sa musel dožadovat vybavenia žiadosti až na Ministerstve vnútra v Pešti, kedže úrady Nitrianskej župy na jeho žiadosț nereagovali (Parenička 2015,143).

Podrobné informácie o púti sú zachytené v spomínanej publikácii Františka Koželuha (2004, 59-177), ktorý stál na čele moravských pútnikov. Zo slovenských pútnikov podrobne informoval slovenskú verejnosṫ na stránkach Katolíckych a Národných novín František V. Sasinek (1881c, 125-126; 1881d, 104-105; 1881f, 2-3). Okrem Katolíckych novín dôležité informácie o púti zanechal pápežský kaplán Juraj Slota v špeciálne vydanej publikácii s názvom Pamiatka putovania katolíckeho Slavianstva do Rímu k hrobu sv. Cyrilla apoštola slavianskeho a ku slávnosti, kterú Jeho Svätost' Pápež - Král' Lev XIII. ku cti svätých Cyrila a Methoda na deň 3., 4. a 5. júlia 1881 v bazilike sv. Klementa zriadit' a vykonat ráćil, ktorú vydal v Prahe roku 1882. V rukopisnej podobe dlho zostali spomienky d’alšieho účastníka púte, račianskeho farára Mórica Alstera. Záznam sa nachádza v kronike rímskokatolíckej fary v Rači s názvom Protocollum ecclesiae et parochiae Récsensis (Zápisnica Chrámu a Fary mestečka Rejcha od r. 1732 do...). Zápis o púti do Ríma, ktorý je na stranách 358-363, zverejnil Jozef V. Gajdoš (1970, 70-73). Na základe týchto prameňov a dobovej tlače vieme podrobne zrekonštruovat’ cestu pútnikov, ako aj samotnú slávnost’ v Ríme.

Pontifik prijal Slovanov na velkolepej osobnej audiencii v Klementínskej kaplnke Vatikánskeho paláca, ktorá sa konala dňa 5. júla 1881. Milodar od slovenských veriacich odovzdal kanonik ostrihomskej kapituly Ján Juriga a pozdravnú adresu Juraj Slota. Práve on na druhý deň počas slávnostnej akadémie predniesol pápežovi a celému zboru kardinálov oslavnú báseň o chvále a cti sv. Cyrila a Metoda a Leva XIII. (1881c, 126-127; Gajdoš 1970, 72). Jej rozsiahly text uverejnili v augustovom čísle Katolíckych novín (KN 1881b, 113-114). O dva mesiace neskôr uvedené noviny zverejnili na prvých dvoch stranách výrazným písmom pozdravný list Leva XIII., ktorým reagoval na slovenskú adresu a prostredníctvom ktorého udelil apoštolské požehnanie (Odpoved' 1881, 145-146). Slovenskí pútnici vnímali účast’ na dakovnej púti v Ríme velmi pozitívne. Račiansky

František V. Sasinek (1881d, 104) vo svojej prvej správe o putovaní do Ríma, ktorú uverejnil v Katolíckych novinách už 15. júla 1881, nespomína medzi pútnikmi zo Slovenska Andreja Kubinu. 
farár Móric Alster záznam o nej končí osobným vyjadrením: „Táto slawjanska pút do Ríma ku cti svätých Cyrila a Metoda je a iste aj ostane najslávnejším momentom celého môjho života. Neoželel som ani podstúpené tažkosti, ani útraty asi 200 zlatých činiace. Iste pre katolika a k tomu radostná príhoda je vidiet rímskeho Otca a mesto Rím, stredisko celého krestanstva. Poznal som i rozličné slawjanske kmene a nadobudol som presvedčenie, že sa všetky vedia porozumiet i bez jednej spoločnej literárnej reči, čo by ovšem k zvel’adeniu Slávskeho Národa slúžilo. Kčomu nech všemohúci Boh, ako aj oslave katolíckej cirkvi na orodovanie sv. Cyrila a Metoda pomáha!" (Gajdoš 1970, 73).

Encyklika Grande munus bola témou Katolíckych novín aj v roku 1882, ked’ číslo 13 vyšlo symbolicky 5. júla s rovnomenným úvodníkom. Autor chváli Leva XIII. za tento počin. Konkrétne uvádza: „Na čele tých, ktorí bez ohladu na atheistický škrek politikárov zasadzujú sa o spojenie velikánskeho Slovanstva s pravým ovčincom Ježišovým, stojí náš milovaný pápež Lev XIII. Dôkazom toho je obsah jeho vznešenej encykliky „Grande munus“, ktorá je jasným dokladom, že Ján VIII. v. p. po tisícročí ožil vo Lvovi XIII. Jako niekdy tamten, tak teraz tento, a to ešte slávnostnejším spôsobom pred Bohom a svetom vydal svedectvo nielen o pravovernosti, lež i o velikánskych zásluhách sv. Cyrilla a Methoda, ked' jich život a poctu sdelil celému svetu katolickému. Jako niekdy tamten schválil užívanie slovanskej reči $k$ vykonávaniu najsvätejších tajomství našeho náboženstva, tak i tento s vel'kou radostou srdca schválil program lanskoročnej rímskej slávnosti, dla ktorej v chráme sv. Klementa pápeža a mučenníka, nad hrobom sv. Cyrilla, konala sa vznešená bohoslužba v jazyku severných (ruských), východných (bulharských) a južných (hlaholských) Slovanov, zajiste v tej nádeji, že slovanský sever, východ a juh Európy vedla latinského západu korit sa bude jednomu Pánu; že sa spojí v $v$ jednotu viery, $v$ ktorej nenie rozdielu medzi pohanom a židom, medzi cudzojazyčníkom a Scythom." (KN 1882, 98). Práve Katolícke noviny aj v nasledujúcich rokoch 19. storočia prispeli k rozvoju úcty k sv. Cyrilovi a Metodovi a šíreniu cyrilo-metodskej tradície na Slovensku (Lopatková 2013, 251-255).

Okrem uvedených článkov, ktoré súvisia s encyklikou Grande munus alebo pútou do Ríma v roku 1881 možno dat do priameho súvisu piesne o sv. Cyrilovi a Metodovi, ktoré sa stali súčastou Duchovného Spewníka, pretože ho zostavil František V. Sasinek. V roku 1937 prešli aj do Jednotného katolíckeho spevníka a spievajú sa dodnes. Medzi tieto piesne patrí Duša krestanská, zvelebuj Boha (č. 431) a Oslavujme hviezdy jasné (č. 432), ktorých texty napísal František V. Sasinek. Pri príležitosti milénia svätého Metoda na základe textu Františka V. Sasinka vznikla pieseň Tisíc rokov preletelo. Oddanost’ a vd’aka Slovákov pápežovi Piovi IX. i Levovi XIII. sa odráža zas v piesňach V srdci Ríma (č. 522) a v Sedmobrežnom kruhu Ríma (č. 523), ktoré textovo pripravil Andrej Radlinský (Hromják 2013, 561; Śátek 1970, 90-93).

Priamo s encyklikou Grande munus možno spájat’ vznik a činnost̉ Apoštolátu sv. Cyrila a Metoda, ktorý bol založený na Velehrade v roku 1885. Jeho idea vychádzala práve z encykliky. Mal za úlohu zjednotit v katolíckej viere všetkých Slovanov a podporovat misie i školy u východných Slovanov. Postupne sa do jeho činnosti zapájali aj slovenskí katolíci (Cinek 1933, 153-254).

\section{Záver}

Cyrilo-metodská tradícia má bohatú históriu. V slovenskom a českom prostredí sa stala v 19. storočí súčastou národného programu. Aj preto encyklika Grande munus pápeža Leva XIII. z roku 1880 našla medzi Slovákmi pozitívnu odozvu, a to predovšetkým u katolíkov. Svedčí o tom fakt, že pod pozdravnú tzv. adresu (pozdravný a dakovný list Sv. Otcovi) pápežovi Levovi XIII. sa podpísalo takmer 4000 veriacich Slovákov a niektorí z nich prispeli na milodar, ktorý bol pápežovi osobne odovzdaný slovenskými pútnikmi 5. júla 1881 v Ríme pri príležitosti dakovnej púte Slovanov. Hoci Slovákov sa jej zúčastnilo málo, ale bol medzi nimi výkvet slovenskej katolíckej 
inteligencie, ktorá aktívne vystupovala aj pred samotným pápežom. Slovenskí veriaci boli informovaní o encyklike i samotnej púti do Ríma vo svojom jazyku na stránkach Katolíckych novín. Vydanie encykliky významne prispelo k národnému povedomiu Slovanov a aj Slovákov, ako aj $\mathrm{k}$ upevneniu cyrilo-metodskej tradície u nich. Priami účastníci púte do Ríma v roku 1881 vnášali svojimi verejnými prejavmi a uverejnenými príspevkami do povedomia slovenskej spoločnosti informácie o význame diela solúnskych bratov pre slovanské národy. Poukazovali na skutočnost', že práve sv. Cyril a Metod šírili krestanskú vieru práve na území, ktoré obývali predkovia Slovákov. Prostredníctvom úcty k solúnskym bratom sa snažili slovenskí vlastenci posilnit vlastnú identitu u Slovákov. Prostredníctvom encykliky sa katolícki veriaci na celom svete oboznámili s najdôležitejšími kultúrnymi hodnotami, ktoré na Vel'kú Moravu priniesli sv. Cyril a Metod z Byzancie. Štúdia je len skromnou sondou do výskumu problematiky. Ďalší výskum by sa mohol zamerat' na podrobnejšiu analýzu percepcie encykliky Grande munus vo vtedajšom slovanskom svete.

\section{REFERENCES}

Ambros Pavel. 2018. Encyklika Lva XIII. Grande munus (1880), apoštolský list sv. Jana Pavla II. Egregiae virtutis (1980) a jejich vliv na proměnu témat a funkcí cyrilometodějské tradice ve 20. a 21. století. In Cyrilometodějská tradice v novodobých československých dějinách. Zlín, 55-63.

Cinek, František. 1933. Dr. Antonín Cyril Stojan. Olomouc.

Gajdoš, Vševlad J. 1970. Cyrilometodovské tisícročie v záznamoch Mórica Alstera. In Dedičstvo otcov. K 1100. výročiu smrti sv. Cyrila a 100. výročiu založenia spolku sv. Vojtecha. Trnava, 63-77.

Grande munus. 2019. Sanctissimi domini nostri Leonis divina providentia Papae XIII littera encyclica Grande munus. http://w2.vatican.va/content/leo-xiii/la/encyclicals/documents/ hf_l-xiii_enc_30091880_grande-munus.html.

Hanakovič, Štefan. 2005. Dejiny Spolku svätého Vojtecha. Trnava.

Hromják, Luboslav. 2010. Lo slavismo cattolico di Leone XIII e gli Slovacchi. Praha.

Hromják, L’uboslav. 2013. Cyrilo-metodský kult a jeho miesto v katolíckom slavizme Leva XIII. In Tradícia a prítomnost misijného diela sv. Cyrila a Metoda. Nitra, 549-550.

Kabina, Franko. 1881. Nemlčme, bo mlčat nemusíme a mlčat nám neslušno. In Katolícke noviny 12/ 4, 15. apríla 1881, 54-55.

KN 1880. Encyklika sv. Otca pápeža Leva XIII. o svätých apoštoloch slovanských Cyrillovi a Methodovi. In Katolícke noviny 11/11, 10. novembra 1880, 161-164.

KN 1881a. Pozvání na pout do Ř́ma. S poděkováním sv. Otci Lvovi XIII. a k slávnosti památky Cyrilla a Methoda dne 5. července. In Katolícke noviny 12/6, 6. júna 1881, 81-82.

KN 1881b. City katolických Slovákov uhorských, vyjjavené od Juraja Slotty, čestného kaplana pápežského, dekana a farára pustavoderadského v Ríme v akademii polyglotnej (mnohojazykovej), ktorá ku cti a chvále Cyrilla a Methoda, apoštolov slovanských v prítomnosti Jeho Svätosti Pána Našeho Leva XIII. a celého sv. Sboru kardinálov v sieni klementinskej v apoštolskom paláci vatikánskom dňa 6 . júla 1881 držaná bola. In Katolícke noviny 12/8, 15. augusta 1881, 113-114.

KN 1882. 5. Júla. In Katolícke noviny 13/13, 5. júla 1881, 97-98.

Kolísek, Alojz. 1935. Cyrillo-Methodějství u Čechů a Slováků do roku 1931. Brno.

Koželuha, František. 2004. Pout Slovanu do Ríma ke dni sv. naších apoštolů Cyrilla a Methodeje r. 1881. In Koželuha, František. Paměti o věcech náboženských. II. svazek. Prostejov, 59-177. 
Lopatková, Zuzana. 2013. Cyrilo-metodská tradícia na stránkach Katolíckych novín (1870 1904). In Tradícia a prítomnost' misijného diela sv. Cyrila a Metoda. Nitra, 244-255.

Odpoved' 1881. Odpoved' sv. Otca Leva XIII. R. P. In Katolícke noviny 12/10, 15. októbra 1881, 145-146.

Parenička, Pavol. 2015. Cesta F. V. Sasinka do Ríma roku 1881 a jej význam pre Slovanov a Slovákov vo svetle dobovej slovenskej periodickej tlače. In Mulík Peter (ed.). Čo písal o našich dejinách Sasinek. Martin 2015, 141-146.

Reč 1881. Reč sv. Otca k pútnikom slovanským pri audiencii dňa 5. júla. In Katolícke noviny 12/8, 15. augusta 1881, 115-116.

Sasinek, František Vítazoslav. 1881a. Milodary. In Katolícke noviny 12/8, 15. augusta 1881, 126.

Sasinek, František Vítazoslav. 1881b. Nuž a my Slováci, čo? In Katolícke noviny 12/3, 15. marca 1881, 36-37.

Sasinek, František Vítazoslav. 1881c. Putovanie do Ríma. Besednica. In Katolícke noviny 12/8, 15. augusta 1881, 125-126.

Sasinek, František Vítazoslav. 1881d. Putovanie do Ríma Dopisy. In Katolícke noviny 12/7, 15. júla 1881, 104-105.

Sasinek, František Vítazoslav. 1881e. Vyzvanie. In Katolícke noviny 12/6, 6. júna 1881, 9.

Sasinek, František Vítazoslav. 1881f. Z denníka mojej púti - besednica. In Národnie noviny 12/89, 2. 8. 1881, 2-3.

Slotta, Juraj. 1882. Pamiatka putovania katolíckeho Slavianstva do Rímu k hrobu sv. Cyrilla apoštola slavianskeho a ku slávnosti, kterú Jeho Svätost’ Pápež - Král Lev XIII. ku cti svätých Cyrila a Methoda na deň 3., 4. a 5. júlia 1881 v bazilike sv. Klementa zriadit’ a vykonat ráčil. Praha.

Šátek, Jozef. 1970. Slovenské cyrilometodovské piesne. In Dedičstvo otcov. K 1100. výročiu smrti sv.Cyrila a 100. výročiu založenia spolku sv. Vojtecha. Trnava, 78-94.

Škvarna, Dušan - Hudek, Adam. 2013. Cyril a Metod v historickom vedomí a pamäti 19. a 20. storočia na Slovensku. Bratislava.

Tolomeo, Rita. 2005. Les Puissances et Léon XIII: la Russie. In The Papacy and the New World Order. Vatican Diplomacy, Catholic Opinion and International Politics at the Time of Leo XIII / La papauté et le nouvel ordre mondial. Diplomatie vaticane, opinion catholique et politique internationale au temps de Leo XIII. Leuven 2005, 195-210.

Tolomeo, Rita. 2015. La visione slava di Leone XIII e il culto cirillo-metodiano. In I Santi Cirillo e Metodio e la loro eredità religiosa e culturale, ponte tra Oriente e Occidente. Cittá del Vaticano, 203-222.

Trincia, Luciano. 2005. The Central Government of the Church in the System of European Powers. In The Papacy and the New World Order. Vatican Diplomacy, Catholic Opinion and International Politics at the Time of Leo XIII / La papaute et le nouvel ordre mondial. Diplomatie vaticane, opinion catholique et politique internationale au temps de Leo XIII. Leuven 2005, 115-136.

SUMMARY: THE ENCYCLICAL GRANDE MUNUS AND A RESPONSE TO IT FROM THE SLOVAK CATHOLICS. In the year 1878 Pontiff Leo XIII came into the office. It was a time when the Papal court found itself isolated in Europe. During its Pontificate Leo XIII internationally strengthened the prestige and moral status of the Papacy. Pope Leo XIII issued the Encyclical Grande Munus on the 30th of September 1880, right at the beginning of his long pontificate. He noted apostolical merits of Sts. Cyril and Methodius there and extended their feast to the whole Church. The feast of Sts. Cyril and Methodius was set on the 5th of July by this Pontiff. The encyclical was warmly accepted by the Slovaks, 
first and foremost by the Catholics. It is proved by the subsequent fact. Almost the 4000 catholic Slovaks put their signature on the thanksgiving letter to Pope Leo XIII and some of them contributed to a charitable gift for him. Slovak pilgrims handed them out to him on the 5th of July 1881 in Rome on the occasion of the thanksgiving pilgrimage of the Slavs. The Slovak catholic believers were informed about the encyclical and pilgrimage to Rome in their language on pages of the Catholic Newspaper. The publication of the encyclical significantly contributed to the national consciousness of the Slavs as well as Slovaks and to the reinforcement of the Cyrillo-Methodian tradition in their countries. The direct attendees of the pilgrimage to Rome in 1881 brought the information on the significance of the Salonica brothers' work for the Slavonic nations into the consciousness of the Slovak society by their public speeches and published studies or articles. They pointed to the fact that right St. Cyril and Methodius spread the Christian faith right on the territory where the Slovaks have been settled. The Slovak patriots tried to strengthen the Slovak identity through the veneration of the Salonica brothers. And through the encyclical the catholic believers across the world were acquainted with the most important cultural values that Sts. Cyril and Methodius, which they brought to Great Moravia.

prof. PhDr. Peter Ivanič, $\mathrm{PhD}$.

Constantine the Philosopher University in Nitra

Faculty of Arts,

Institute for Research of Constantine and Methodius' Cultural Heritage,

Štefánikova 67

94974 Nitra

Slovakia

pivanic@ukf.sk 